\title{
PRKCI wt Allele
}

National Cancer Institute

\section{Source}

National Cancer Institute. PRKCI wt Allele. NCI Thesaurus. Code C104802.

Human PRKCI wild-type allele is located in the vicinity of $3 q 26.3$ and is approximately 84 $\mathrm{kb}$ in length. This allele, which encodes protein kinase $\mathrm{C}$ iota type protein, is involved in both apoptosis and protein phosphorylation. 